\title{
PEMEKARAN DESA DAN IMPLIKASINYA TERHADAP \\ KEHIDUPAN MASYARAKAT
}

(Studi Kasus di Desa Kramat Jaya Kecamatan Malausma Kabupaten

Majalengka)

\author{
Meli Lutpiah, Suryadi, M.Si, Fuad Faizi, MA \\ Jurusan Pengembangan Masyarakat Islam \\ Fakultas Ushuluddin Adab dan Dakwah \\ IAIN Syekh Nurjati Cirebon \\ E-mail: melilutfiani@ymail.com
}

\begin{abstract}
Village Desa Kramat Jaya is a result of the division which was originally a part of the village Werasari. Expansion of the village is one of the steps the government in the distribution of development in an effort to improve the welfare of society through a policy of regional expansion. This research method is descriptive qualitative method with data collection through interviews, observation, documentation and literature. The results of his research is the process of expansion Desa Kramat Jaya stems from government policies as a driver of the expansion, public aspirations at the hamlet, village expansion plan study Kramat Jaya at the village level, the submission to the expansion of local government, and the inauguration of Desa Kramat Jaya. The division has implications for the lives of the people in the village of Kramat Jaya, such as government reform Desa Kramat Jaya, the impact of the reallocation of village on the lives of farmers through the establishment of Farmers Group Association (Gapoktan), and increased welfare through the development of infrastructure such as, village offices, village health post (Poskesdes), rural roads, rural feeder roads, retaining walls (TPT) or irrigation channels, and kiosks.
\end{abstract}

Keyword: process, the implications, the expansion of the village, the community 


\section{PENDAHULUAH}

Undang-Undang Nomor 32 Tentang Pemerintah Daerah telah mendorong perubahan dalam pelaksanaan pemerintah daerah, seperti maraknya fenomena pemekaran daerah di Indonesia. Pemekaran daerah adalah pemecahan suatu daerah menjadi dua atau lebih daerah dan menjadi salah satu cara pembentukan daerah baru sebagai daerah otonomi. Fenomena pemekaran daerah muncul karena adanya keterbukaan ruang dan kesempatan bagi pemerintah daerah, untuk melakukan pembentukan daerah baru sebagai langkah proses pelaksanaan otonomi daerah. Hal ini terjadi didukung oleh perkembangan rentang geografis yang luas, kondisi sosial yang beragam, dan jumlah penduduk yang meningkat telah berpengaruh terhadap kemampuan pemerintah daerah dalam melaksanakan pemerataan pembangunan melalui pemekaran daerah.

Menurut Ratnawati (2009: 23) "Tujuan pembentukan, pemekaran, penghapusan dan penggabungan daerah adalah untuk meningkatkan kesejahteraan rakyat melalui peningkatan pelayanan, percepatan demokrasi, percepatan perekonomian daerah, percepatan pengelolaan potensi daerah, peningkatan keamanan dan ketertiban, serta peningkatan hubungan serasi antara pusat dan daerah". Oleh karenanya pembangunan diarahkan pada terciptanya pembangunan yang selaras antara kebutuhan dan sumber daya yang dimiliki masyarakat, serta peningkatan kapasitas masyarakat untuk menghadapi berbagai persoalan yang terus berkembang.

Pemekaran daerah di Indonesia telah banyak terjadi di berbagai daerah, tidak hanya terjadi pada tingkat provinsi, melainkan pada tingkat kabupaten atau kota, kecamatan atau kelurahan bahkan dalam lingkup wilayah adminstrasi terkecil yaitu desa. Pemekaran desa-desa juga terjadi di Kabupaten Majalengka dalam kurun waktu 2 tahun sejak tahun 2010-2012 terdapat 9 pembentukan desa baru (BAPEDA Kabupaten Majalengka Tahun 2012).

Pada tahun 2012 kebijakan pemerintah daerah Kabupaten Majalengka terkait dengan pemekaran desa salah satunya adalah pemekaran Desa Kramat Jaya dari Desa Werasari. Desa Kramat Jaya merupakan desa baru hasil pemekaran di Kecamatan Malausma yang ditetapkan melalui Peraturan Daerah Kabupaten Majalengka Nomor 12 Tahun 2012 Tentang Pembentukan Desa Kramat Jaya. Desa Kramat Jaya resmi menjadi sebuah desa baru pada 4 Desember 2012 dengan dilantiknya pejabat sementara kepala desa yaitu Pak Umu Mu'minin oleh Bupati Kabupaten Majalengka.

Kebijakan pemekaran Desa Kramat Jaya, muncul sebagai respon terhadap kondisi permasalahan masyarakat yang membutuhkan adanya pemerataan pembangunan. Fenomena yang berkembang sebelum pemekaran desa adalah Desa Werasari yang menjadi induk dari Dusun Cimanglid secara umum merupakan kawasan desa yang padat penduduknya karena pertumbuhan penduduk yang cukup pesat.

Kepadatan pendudukk Desa Werasari tercatat sebanyak 6.208 jiwa dengan jumlah kepala keluarga sebanyak 1.807.

Pertumbuhan penduduk yang cukup pesat di Desa Werasari berdampak pada pola pemukiman penduduk setempat. Pemukiman penduduk disetiap blok dan dusun semakin meluas dan menyebar menjauhi pusat pemerintahan Desa Werasari. Hal ini tentu memperluas jangkauan pemerintah desa dalam memberikan pelayanan kepada masyarakat. Tanggung jawab yang diemban oleh 
pemerintah desa juga semakin besar dalam meningkatkan kesejahteraan masyarakat dan pemerataan pembangunan di setiap blok dan dusun.

Pemekaran Desa Kramat Jaya dilaksanakan atas dasar pertimbangan bahwa dengan semakin meningkatnya jumlah penduduk, efektivitas kegiatan pemerintahan dan pembangunan dalam wilayah Desa Werasari Kecamatan Malausma, maka untuk meningkatkan pelayanan publik guna mempercepat terwujudnya kesejahteraan masyarakat dipandang perlu melakukan pembentukan desa melalui pemekaran desa.

Berdirinya Desa Kramat Jaya sebagai sebuah desa baru yang otonom, memiliki tugas dan tanggung jawab yang sama seperti desa-desa pada umumnya untuk menyelenggarakan pemerintahan desa secara mandiri. Pemerintah desa memiliki tanggung jawab atas masyarakat dan wilayah administratif desa, serta bertugas untuk menyelenggarakan pemerintahan desa, melaksanakan pembangunan desa, pembinaan kemasyarakatan, dan pemberdayaan masyarakat desa untuk meningkatakan kualitas hidup dan kesejahteraan masyarakat.

Fenomena pemekaran Desa Kramat Jaya merupakan sebuah perubahan sosial dalam tatanan kelembagaan secara struktural dan sistemik. Perubahan sosial tersebut berkaitan dengan kebijakan berupa peraturan daerah dengan tujuan pemerataan pembangunan dan kesejahteraan masyarakat. Hal ini menarik untuk diteliti, dengan mengkaji lebih dalam fenomena pemekaran Desa Kramat Jaya.

Dengan demikian, tujuan penelitian ini adalah sebagai berikut:

1. Untuk mengetahui proses pemekaran Desa Kramat Jaya.
2. Untuk mengetahui implikasi pemekaran desa terhadap kehidupan masyarakat di Desa Kramat Jaya.

\section{KAJIAN PUSTAKA}

1. Konsep Pemekaran Daerah

Pemekaran daerah berarti pengembangan dari satu daerah otonom menjadi dua atau lebih daerah otonom (Wijoyo, 2013: 21). Pembahasan tentang pemekaran daerah terdapat pada pasal 4 ayat 3 dan ayat 4 Undang-Undang Nomor 32 Tahun 2004 Tentang Pemerintahan Daerah. Pembentukan daerah dapat berupa penggabungan beberapa daerah atau bagian daerah yang bersandingan atau pemekaran dari satu daerah menjadi dua daerah atau lebih.

Pemekaran daerah merupakan salah satu cara pembentukan daerah baru sebagai daerah otonomi berdasarkan pertimbangan kemampuan ekonomi, potensi daerah, sosial-budaya, sosialpolitik, jumlah penduduk, luas daerah, dan pertimbangan lain yang memungkinkan terselenggaranya otonomi daerah. Selain itu dibarengi dengan perbaikan-perbaikan yang mendasar, terutama pada sumber daya manusianya karena sebelumnya telah terbiasa pada sistem yang serba pasif dan hanya menunggu keputusan (Chalid, 2005:23). Ratnawati (2009: 10-11) menjelaskan bahwa pada dasarnya pemekaran daerah memiliki pandangan untuk meningkatakan kesejahteraan masyarakat, mengembangkan demokrasi lokal, memaksimalkan akses publik ke pemerintah, mendekatkan pemerintah dengan rakyatnya, menyediakan pelayanan publik sebaik dan seefisien mungkin. 
2. Konsep Pemekaran Desa

Pemekaran desa adalah pemecahan satu wilayah desa menjadi dua atau lebih dengan pertimbangan karena keluasan wilayahnya, kondisi geografis, pertumbuhan jumlah penduduk, efektifitas dan efisensi dalam pelayanan publik serta kondisi sosial politik yang ada (Yunaldi dalam Sapi'i, 2008). Peraturan Menteri Dalam Negeri Nomor 28 Tahun 2006 pasal 1 ayat 7, disebutkan bahwa "Pembentukan Desa adalah penggabungan beberapa desa, atau bagian desa yang bersandingan, atau pemekaran dari satu desa menjadi dua desa atau lebih, atau pembentukan desa di luar desa yang telah ada". Pemekaran desa pada dasarnya merupakan suatu proses pembagian wilayah desa menjadi lebih dari satu wilayah atas dasar prakarsa masyarakat dengan memperhatikan asal-usul dan adat istiadat maupun sosial budaya masyarakat setempat.

3. Konsep Perubahan Sosial

Perubahan senantiasa dialami oleh setiap masyarakat manusia selama hidupnya. Perubahanperubahan yang terjadi dalam masyarakat dapat mengenai nilai-nilai sosial, norma-norma sosial, pola-pola prilaku organisasi, susunan lembaga kemasyarakatan, lapisanlapisan dalam masyarakat, kekuasaan dan wewenang, interaksi sosial dan lain sebagianya (Soekanto, 2007: 259).

4. Konsep Pembangunan Masyarakat

Menurut Soetomo (2012: 6) masyarakat pada dasarnya senantiasa mengalami proses perubahan baik secara cepat maupun lambat dan tidak lepas dari berbagai masalah sosial yang menyertainya mendorong untuk melakukan perbaikan dari kondisi yang tidak diharapakan (sosial illfare) menuju kondisi ideal atau masyarakat sejahtera (sosial welfare). Proses perubahan tersebut merupakan bentuk perkembangan masyarakat (development) atau yang dikenal dengan istilah pembangunan yang diartikan sebagai salah satu teori bahkan ideologi tentang perubahan sosial, dan realitas kehidupan masyarakat yang berupaya menuju kondisi ideal.

Menurut Long (dalam Soetomo, 2012: 119) klasifikasi perubahan struktural dalam perencanaan dan pelaksanaan pembangunan masyarakat adalah transformation approach dan improvement approach. Transformation approach adalah pendekatan dalam pembangunan dalam masyarakat yang memiliki kadar yang tinggi dalam mewujudkan perubahan struktural, sistem dan institusi yang berasal dari aspek moral, sosial dan ekonomi. Improvement approach adalah pendekatan pembangunan yang memperkenalkan dan mendorong perubahan dalam berbagai aspek kehidupan, dengan masih memberikan toleransi pada struktur yang ada sehingga tidak harus melakukan perubahan struktural.

\section{METODE PENELITIAN Lokasi \\ Penelitian}

Lokasi penelitian di Desa Kramat Jaya Kecamatan Malausma Kabupaten Majalengka.

\section{Metode Penelitian}

Penelitian ini menggunakan metode penelitian kualitatif deskriptif yaitu mendeskripsikan hasil penelitian terkait dalam bentuk kata-kata dan bahasa. Penelitian bertujuan mendeskripsikan dan menguraikan kondisi sosial masyarakat, proses perubahan sosial pemekaran desa, 
dan implikasinya terhadap kehidupan masyarakat. Penelitian deskripitif kualitatif dilakukan dalam bentuk studi kasus tertentu yakni memusatkan diri pada suatu unit masyarakat Desa Kramat Jaya secara mendalam.

\section{Metode Pengumpulan Data}

Metode pengumpulan data yang dilakukan adalah peneliti secara langsung turun lapangan mengamati realitas kehidupan masyarakat Desa Kramat Jaya. Teknik pengumpulan data melalui wawancara, observasi, dan dokumentasi. Pertama, teknik wawancara, peneliti berdialog dengan informan terkait kondisi sosial masyarakat setempat dan pemekaran desa. Kedua, metode observasi, peneliti terlibat dengan kegiatan sehari-hari masyarakat dalam rangka menghimpun data penelitian berdasarkan atas pengalaman langsung, dan pengindraan. Ketiga, metode dokumentasi terhadap hasil wawancara dan observasi melalui catatan lapangan, rekaman, foto, dan video, dan studi pustaka dengan membaca berbagai referensi seperti buku, artikel, jurnal, skripsi, dan hasil penelitian-penelitan terdahulu yang berkaitan dengan topik pemekaran desa.

\section{Informan Penelitian}

Informan dalam penelitian ini diantaranya adalah pertama, warga masyarakat di Dusun Cimanglid, Dusun Babakan dan Dusun Cikondang. Kedua, pemerintah Desa Werasari. Ketiga, pemerintah Desa Kramat Jaya.

\section{Metode Analisis Data}

Analisis data pada saat pengumpulan data di lapangan, peneliti menggunakan teknik analisis data model Miles dan Huberman yaitu terdapat tiga tahapan seperti reduksi data, display data atau penyajian data, dan verifikasi (Sugiyono, 2011: 246).

\section{HASIL DAN PEMBAHASAN \\ CIMANGLID MENUJU PEMEKARAN \\ DESA}

\section{A. Tempo Dulu: Cimanglid Sebelum} Pemekaran Desa

1. Sketsa Geografis Dusun

Cimanglid

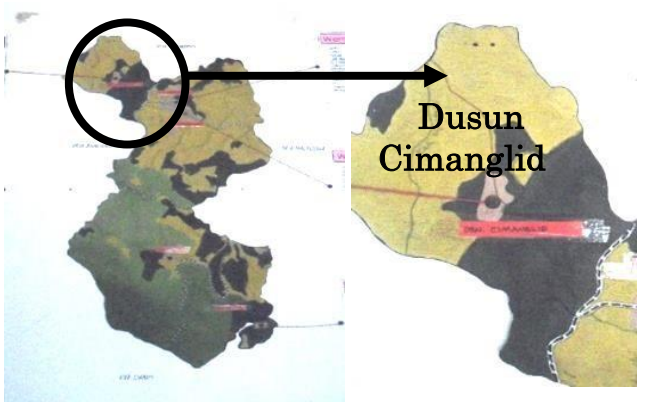

Gambar 1: Peta Desa Werasari-Dusun Cimanglid, Kabupaten Ciamis

Dusun Cimanglid merupakan salah satu dusun bagian dari Desa Werasari yang terletak paling ujung arah barat laut dan berbatasan dengan Desa Buninagara dan Desa Cipeundeuy. Desa Werasari terdiri dari 7 blok dan 3 dusun, yaitu Blok Ahad, Blok Senin, Blok Selasa, Blok Rabu, Blok Kamis, Blok Jum'at, Blok Sabtu, Dusun Walahir, Dusun Cipicung, dan Dusun Cimanglid. Desa Werasari sebagai desa induk Dusun Cimanglid, memiliki luas wilayah 506,4 Ha. Batas-batas Desa Werasari adalah sebagai berikut: Sebelah Utara; Desa Cipeundeuy, Sebeleh Timur; Desa Malausma, Sebelah Selatan; Desa Tengger Raharja, Sebelah Barat; Desa Buninagara.

Dusun Cimanglid ini memiliki kampung yang cukup terpental, dipisahkan oleh pesawahan yaitu bernama Kampung Cikondang. 


\section{Potret Kehidupan Masyarakat di Dusun Cimanglid}

Kehidupan sosial ekonomi masyarakat di Dusun Cimanglid mayoritas bermatapencaharian sebagai petani. Petani di Dusun Cimanglid termasuk kategori subsisten yaitu bertani dan hasilnya hanya digunakan untuk konsumsi sendiri dan tidak dikomersilkan. Selain potensi pertanian, adapula potensi perdagangan, dan industri. Industri yang terdapat di Dusun Cimanglid adalah maknan olahan, kerupuk, batu bata, penyulingan minyak cengkeh, kayu, mebeul, dan matrial bangunan.

Fenomena yang berkembang sebelum pemekaran desa, Desa Werasari secara umum merupakan kawasan desa yang padat penduduknya dan mengalami pertumbuhan penduduk yang cukup pesat. Data Kependudukan Desa Werasari sampai awal Bulan Januari 2011 tercatat sebanyak 6.208 jiwa dengan jumlah kepala keluarga 1.807. Jumlah penduduk tersebut, terdiri dari 1.666 jiwa penduduknya berasal dari wilayah Dusun Cimanglid dan Kampung Sampalan (Profil Desa Werasari Tahun 2011). Kampung Sampalan merupakan kampung yang masih menjadi bagian dari Blok Kamis. Cakupan wilayah Desa Werasari juga luas yaitu 506,4 Ha.

Pertumbuhan penduduk yang cukup pesat membuat pemukiman penduduk disetiap blok dan dusun semakin meluas dan menyebar menjauhi pusat pemerintahan Desa Werasari. Hal ini tentu memperluas jangkauan pemerintah desa dalam memberikan pelayanan kepada masyarakat. Tanggung jawab yang diemban oleh pemerintah desa juga semakin besar dalam meningkatkan kesejahteraan masyarakat dan pemerataan pembangunan di setiap blok dan dusun.

Dusun Cimanglid merupakan dusun yang terletak bersebelahan dengan Desa Buninagara dan Desa Cipeundeuy. Wilayah Dusun Cimangid dilalui oleh jalan desa dan menjadi wilayah yang cukup strategis. Posisi strategis tersebut tidak didukung oleh sarana transfortasi berupa jalan yang memadai, karena kondisi jalan dalam keadaan rusak parah. Keadaan jalan tersebut, masyarakat sudah menyampaikannya kepada pemerintah Desa Werasari dan meminta untuk segera diperbaiki, tetapi aspirasi yang disampaikan masyarakat ke pemerintah desa sulit dipenuhi karena banyaknya pembangunan yang harus dilaksankan oleh pemerintah desa.

Ditinjau dari letak geografis, Dusun Cimanglid yaitu cukup terpental dan jauh dari pusat pemerintahan Desa Werasari. Masyarakat yang membutuhkan pelayanan pemerintah desa seperti administrasi kependudukan, kartu Tanda Penduduk (KTP) atau kartu keluarga harus menempuh jarak $1 \mathrm{Km}$ terlebih dahulu. Pemenuhan pelayanan dari pemerintah juga cukup lama, karena banyaknya penduduk yang harus diberi pelayanan oleh pemerintah desa.

Pelayanan kesehatan yang ada di Dusun Cimanglid hanya ada 1 yaitu berupa Pos Pelayanan Terpadu (Posyandu). Pelaksanaan Posyandu tersebut rutin diadakan satu kali dalam 
sebulan dan harus melayani atau melaksanakan pemeriksaan kesehatan pada anak-anak balita dan ibu-ibu hamil. Waktu tempuh masyarakat untuk mendapatkan pelayanan dari Posyandu membutuhkan waktu yang cukup lama dan tenaga karena biasanya ditempuh dengan jalan kaki.

\section{B. Proses Pemekaran Desa Kramat Jaya}

\section{Kebijakan Sebagai Pendorong Pemekaran}

Pemekaran daerah di Indonesia semakin berkembang sejak masa reformasi sampai sekarang dan menjadi kecenderungan baru dalam struktur pemerintahan di Indonesia, karena banyak pembentukan daerah baru. Hal ini terlihat sejak dikeluarkannya Undang-Undang Nomor 32 Tahun 2004 Tentang Pemerintah Daerah. Begitupun dengan pemekaran Desa Kramat Jaya, dipengaruhi oleh adanya kebijakan otonomi daerah yang tertera dalam peraturan perundangundangan Tentang Pemerintah Daerah tersebut. Pemekaran Desa Kramat Jaya di dukung oleh kebijakan-kebijakan lainnya yaitu:

a. Peraturan Menteri Dalam Negeri Nomor 28 Tahun 2006 Tentang Pembentukan, Penghapusan, Penggabungan Desa dan Perubahan Status Desa menjadi Kelurahan.

b. Peraturan Daerah Kabupaten Majalengka Nomor 17 Tahun 2006 Tentang Pembentukan,

Penggabungan dan Penghapusan Desa di Kabupaten Majalengka.

Peraturan-peraturan tersebut di atas, secara tidak langsung telah mendorong masyarakat untuk pemekaran Desa Kramat Jaya.
Penawaran pemekaran desa dari Pemerintah Desa Werasari kepada masyarakat Dusun Cimanglid juga menjadi awal pertimbangan adanya pemekaran. Bersamaan dengan penawaran pemekaran pada masyarakat Dusun Cimanglid, pada saat itu penawaran pemekaran desa diberikan pula kepada masyarakat Dusun Cipicung yang masih menjadi bagian dari Desa Werasari, tetapi tidak direspon secara berkelanjutan.

Tawaran pemekaran desa, pada mulanya direspon oleh salah satu tokoh masyarakat Dusun Cimanglid, yaitu Bapak Umu Mu'minin. Pak Umu Mu'minin kemudian menjadi penggerak masyarakat Dusun Cimanglid dan Kampung Sampalan untuk mengusulkan pemekaran desa.

\section{Penjaringan Aspirasi Masyarakat di Tingkat Dusun}

Musyawarah tingkat dusun membahasa hal berikut:

Pertama, kesepakatan adanya pemekaran desa, hal ini menjadi suatu hal yang sangat penting karena pemekaran desa harus berdasarkan atas prakarsa dan inisiatif masyarakat. Masyarakat pada dasarnya senantiasa mengalami proses perubahan yang mendorong untuk melakukan perbaikan dari kondisi yang tidak diharapkan (sosial illfare) menuju kondisi ideal atau sejahtera (sosial welfare) (Soetomo, 2012: 6). Pemekaran desa merupakan bagian dari usaha dan harapan masyarakat untuk melaksanakan perubahan sosial untuk dapat hidup lebih baik.

Kedua, pembentukan panitia pemekaran desa. Panitia pemekaran desa diketuai oleh Pak Umu Mu'minin. 
Ketiga, rencana penamaan desa. Rencana penamaan desa baru setelah pemekaran adalah memakai nama "Kramat Jaya" yaitu perpaduan dari dua nama makam sejarah Kramat Buyut Bagi dan Brahma Jaya yang ada di Dusun Cimanglid.

Keempat, merumuskan maksud dan tujuan pemekaran desa. Maksud dan tujuan yang ditentukan berdasarkan permasalahan masyarakat pada tahap awal, dapat menentukan keberhasilan langkah-langkah berikutnya, bahkan menentukan hasil akhir (Soetomo, 2012: 79).

Maksud dan tujuan pemekaran desa diantaranya adalah sebagai berikut:

1) Meningkatkan dan mendekatkan pelayanan masyarakat;

2) Pemerataan pembangunan;

3) Menumbuh kembangkan kerukunan hidup bermasyarakat, beragama dan bernegara dalam upaya mewujudkan desa mandiri atas prakarsa masyarakat desa sendiri;

4) Potensi Dusun Cimanglid, Dusun Cikondang dan Dusun Babakan yang dapat dikembangkan yaitu sektor pertanian, sektor peternakan, dan industri. Dusun Cikondang dan Dusun Babakan merupakan dusun baru hasil pecahan dari Dusun Cimanglid dan penyatuan wilayah kampung Sampalan yang direncanakan akan masuk wilayah Desa Kramat Jaya.

5) Membangun desa baru yang meliputi wilayah Dusun Cimanglid, Dusun Cikondang dan Dusun

\footnotetext{
${ }^{1}$ Wawancara dengan Pak Umu, Pak Dudin ${ }^{2}$ Wawancara dengan Pak Urip, Ibu Titin, Pak Idus
}

Babakan; dan

6) Menumbuh kembangkan rasa kekeluargaan dan gotong royong untuk menuju masyarakat yang rukun, kuat, mandiri dalam suatu kerangka sebuah desa. ${ }^{1}$

Hasil musyawarah tersebut di atas diajukan ke pemerintah Desa Werasari. Proses pengusulan pemekaran Desa Kramat Jaya berikutnya, hanya diwakili oleh beberapa tokoh saja sebagaimana yang terbentuk dalam kepanitiaan pemekaran desa. Sebagian besar masyarakat Dusun Cimanglid, Dusun Babakan dan Dusun Cikondang cenderung mempercayakan dan menyetujui adanya pemekaran, tidak terlalu ikut campur dalam tahapan berikutnya. $^{2}$

Nilai-nilai yang berkembang dalam masyarakat Dusun Cimanglid salah satunya adalah rasa saling percaya (trust) karena individuindividu dalam masyarakat cenderung mempercayakan kepada panitia pemekaran untuk mengurus proses pemekaran. ${ }^{3}$ Nilai rasa saling percaya (trust) yang terdapat dalam kehidupan sosial masyarakat mendorong individu-individu untuk bersedia menggunakan hasil kerja orang atau kelompok lain (Soetomo, 2012: 202).

\section{Kajian Rencana Pemekaran Desa Kramat Jaya di Tingkat Desa}

Menanggapi usulan pemekaran dari masyarakat, pemerintah Desa Werasari mengadakan musyawarahmusyawarah tingkat desa.

1) Menanggapi Usulan Pemekaran melalui Rapat BPD

${ }^{3}$ Wawancara dengan Pak Idus, Ibu Titin, Ibu Entin, Ibu Yuli 
BPD mengadakan rapat

mengenai musyawarah usulan pemekaran Desa Kramat Jaya. Rapat tersebut dihadiri oleh, pemerintah desa, LPM, tokoh masyarakat, tokoh agama, tokoh pendidikan, tokoh pemuda, tokoh perempuan, dan masyarakat atas nama Dusun Cimanglid, Dusun Cikondang, dan Dusun Babakan. Rapat BPD bersama berbagai elemen masyarakat mengenai musyawarah usulan pemekaran Desa Kramat Jaya adalah menyetujui adanya pemekaran desa.

2) Rapat pleno

Rapat pleno BPD sepakat dan menyetujui usulan pemekaran Desa Kramat Jaya dari Desa Werasari dengan berbagai pertimbangan. Pertimbangannya adalah pelayanan Pemerintah Desa Werasari kepada masyarakat Dusun Cimanglid, Dusun Cikondang dan Dusun Babakan belum optimal.

Letak geografis yang cukup jauh dari pusat pemerintahan Desa Werasari, yaitu kurang lebih 2 kilo meter, jumlah penduduk mengalami peningkatan yang cukup pesat sehingga pemukiman penduduk meluas, sementara jumlah penduduk untuk yang direncanakan akan masuk pada Desa Kramat Jaya sudah mencukupi untuk berdiri membentuk desa otonom. Dengan demikian dalam musyawarah membahas tentang persyaratan teknis dan fisik kewilayahan pembentukan Desa Kramat Jaya.

Pembahasan persyaratan pemekaran desa ini menjadi hal yang sangat penting karena pemekaran desa tidak hanya pemecahan satu wilayah desa menjadi dua atau lebih, tetapi harus mempertimbangkan keluasan wilayahnya, kondisi geografis, pertumbuhan jumlah penduduk, efektifitas dan efisensi dalam pelayanan publik serta kondisi sosial politik yang ada (Yunaldi dalam Sapi'i, 2008).

3) Kajian Persyaratan Teknis Pembentukan Desa Kramat Jaya Persyaratan teknis pembentukan Desa Kramat Jaya dalam aspek kependudukan dilihat dari jumlah penduduk Desa Werasari sebelum pemekaran sejumlah 6.270 jiwa dan 1.807 KK. Setelah pemekaran menjadi 4.604 jiwa dan $1.406 \mathrm{KK}$, sementara untuk Desa Kramat jaya hasil pemekaran jumlah penduduknya sejumlah 1.666 jiwa dan $401 \mathrm{KK}$.

Kendala yang dihadapi adalah menyangkut persetujuan dari sebagian masyarakat Kampung Sampalan yang akan masuk bagian dari Dusun Babakan Desa Kramat Jaya. Masyarakat Kampung Sampalan sebagian ada yang berasal dari keturunan Blok Kamis dan sebagian dari Dusun Cimanglid. Masyarakat yang tidak menyetujui adalah masyarakat yang semula berasal dari Blok Kamis karena tidak ingin lepas dari Desa Werasari, sesepuh dan keluarga nenek moyangnya. Selain itu tidak ingin ikut menjadi bagian dari Desa Kramat Jaya karena masih desa baru dan belum mapan. 
Kendala dalam penentuan batas Desa Kramat Jaya dengan Desa Werasari masih berkaitan dengan persetujuan masyarakat Kampung Sampalan yang menginginkan batas desanya berupa persimpangan jalan yang dekat Dusun Cimanglid. Sehingga mereka tetap bisa menjadi bagian dari Desa Werasari. Namun, usaha konsolidasi dilakukan oleh panitia pemekaran dan pemerintah Desa Werasari yang akhirnya masyarakat setuju dengan pemekaran. Persetujuan tersebut dapat memenuhi persyaratan jumlah penduduk desa baru. ${ }^{4}$ Kendala tersebut, menggambarkan bahwa arti penting pemekaran desa belum berhasil disosialisasikan secara menyeluruh kepada masyarakat dengan maksimal. Sehingga terjadi berbagai polemik dalam masyarakat yaitu ada yang setuju dan tidak setuju.

Persyaratan teknis pemekaran desa berupa jumlah penduduk merupakan persyaratan yang berkaitan dengan sumber daya manusia. Pemenuhan persyaratan jumlah penduduk hendaknya tidak hanya dilihat dari kuantitas saja tetapi dilihat dari kualitas dan sudut sosialnya. Sudut sosial manusia yaitu posisinya sebagai individu dan anggota masyarakat yang meliputi kapasitasnya untuk berproduksi, pemerataan, pemberian kekuasaan dan wewenang, kelangsungan untuk berkembang (Effendi, dalam
Soeroto

2012:

194).

Kecenderungan yang terjadi adalah identifikasi jumlah penduduk hanya fokus pada jumlah atau kuantitas.

Persyaratan teknis terkait dengan batas-batas desa yang disepakati adalah Sebelah Utara; Desa Cipeundeuy, Sebelah Timur; Desa Malausma, Sebelah Selatan; Desa Tengger Raharja, Sebelah Barat; Desa Buninagara dan Desa Kramat Jaya. Batas-batas Desa Kramat Jaya adalah: Sebalah Utara; Desa Cipeundeuy, Sebelah Timur; Desa Werasari, Sebelah Selatan; Desa Buninagara, Sebelah Barat; Desa Buninagara

Batas-batas desa tersebut berkaitan dengan pembagian luas wilayah desa. Desa Werasari sebelum pemekaran adalah 506.4 Ha menjadi 376,4 Ha, sementara luas wilayah untuk Desa Kramat Jaya hasil pemekaran adalah 130 Ha.

Batas-batas wilayah desa menjadi acuan dalam menganalisis potensi sumber daya alam yang tersedia dalam lingkup wilayah seluas 130 Ha di Desa Kramat Jaya yang perlu diidentifikasi. Sumber daya alam dapat mencakup makhluk hidup seperti tumbuhtumbuhan dan hewan dan bukan makhluk hidup yaitu tanah, air, batuan, barang tambang, bahan mineral dan lain-lain (Soetomo, 2012: 188). Sumber daya alam yang tersedia dalam lingkup Desa Kramat Jaya adalah berupa lahan

\footnotetext{
${ }^{4}$ Wawancara dengan Pak Umu, Pak Wahid, Pak Dudin
} 
pertanian yang subur seluas $45 \mathrm{Ha}$, sumber air yaitu sungai Cipetek dan Sungai Lebak Cipeundeuy, dan perkebunan (Profil Desa Kramat Jaya).

Wilayah Desa Kramat Jaya juga memiliki situs sejarah penyebaran agama Islam yaitu makam Syekh Mahmud yang diangap Kramat atau yang sering disebut Makan Buyut Bagi terletak di Dusun Babakan dan makam Brahma Jaya yang terletak di Dusun Cimanglid dekat Pusat Pemerintaha Desa. Kedua situs sejarah ini menjadi daya tarik bagi masyarakat luar untuk berkunjung dan berziarah. Selain itu situs tersebut diabadikan dalam penamaan desa yaitu Desa Kramat Jaya. $^{5}$

4) Kajian Persyaratan Fisik Kewilayahan Desa Kramat Jaya

Persyaratan fisik kewilayahan Desa Kramat Jaya hasil pemekaran terdiri dari 3 dusun, yaitu Dusun Cimanglid, Dusun Babakan dan Dusun Cikondang. Dusun Babakan dan Dusun Cikondang adalah dusun baru hasil pecahan dari Dusun Cimanglid dan penyatuan wilayah Kampung Sampalan. Dengan demikian jumlah minimal Blok atau dusun dalam suatu desa telah terpenuhi yaitu sebanyak 3 dusun.

Ketiga dusun yang berada di bawah cakupan wilayah administratif Desa Kramat Jaya dapat dijangkau dalam meningkatkan pemerataan pemabangunan dan pembinaan, serta memiliki jaringan perhubungan atau komunikasi. Persyaratan fisik lainnya adalah Mesjid dan Mushola, sarana pendidikan SD Negeri dan TK, sarana olahraga, serta sarana transportasi berupa jalan desa.

5) Penetapan Keputusan BPD dan Peraturan Desa

Menimbang beberapa hal seperti usulan masyarakat untuk pemekaran Desa Kramat Jaya, dan hasil musyawarah tingkat desa, maka BPD menetapkan Keputusan Badan Permusyawaratan Desa Werasari Tentang Usulan Pemekaran Desa Kramat Jaya. Dengan demikian, pemerintah Desa Werasari baru menetapkan Peraturan Desa.

Peraturan Desa Werasari Tentang Usulan Pembentukan Desa Kramat Jaya ditetapkan berdasarkan persetujuan dari BPD atas pertimbangan untuk kelancaran pemerintahan yang berdaya guna dan berhasil guna dan melayani masyarakat secara optimal sesuai dengan perkembangan pembangunan.

Hasil berbagai musyawarah tingkat desa dituangkan dalam proposal dan dilaporakan ke Pemerintah Kecamatan Malausma untuk mendapatkan rekomendasi pemekaran Desa Kramat Jaya. Setelah mendapatkan rekomendasi dari Kecamatan Malausma, rencana pemekaran Desa Kramat Jaya tersebut diajukan kepada Bupati Pemerintah Daerah

\footnotetext{
${ }^{5}$ Wawancara dengan Pak Urip, Pak Muhdi
} 
Kabupaten Majalengka melalui kecamatan. ${ }^{6}$

\section{Pengajuan Pemekaran kepada Pemerintah Daerah}

Pengajuan pemekaran kepada Pemerintah Daerah dilakukan oleh ketua panitia pemekaran, sekretaris desa, dan perwakilan dari pemerintah kecamatan. $^{7} \quad$ Pada akhirnya Rancangan Peraturan Daerah tentang Pembentukan Desa Kramat Jaya ditetapkan oleh Bupati Kabupaten Majalengka yaitu Peraturan Daerah Kabupaten Majalengka Nomor 12 Tahun 2012 Tentang Pembentukan Desa Kramat Jaya Kecamatan Malausma Kabupaten Majalengka pada tanggal 21 September 2012. Peraturan Daerah tersebut menjadi pelengkap persyaratan pemekaran Desa Kramat Jaya yaitu syarat administratif berupa Peraturan Daerah sebagai persetujuan dari Bupati Pemerintah Daerah dan DPRD.

Persyaratan administratif pemekaran desa berupa persetujuan dari Bupati Pemerintah Daerah dan DPRD merupakan bentuk intervensi dari pemerintah daerah Kabupaten Majalengka untuk melaksanakan pemerataan pembangunan. Intervensi yang dilaksanakan yaitu termasuk model pemerataan. Intervensi model pemerataan didasarkan atas pemahaman bahwa sumber masalahnya adalah ketidakmerataan yang disebabkan oleh masalah struktur, sehingga langkah yang diambil adalah melaksanakan sebuah perubahan melalui kebijakan (Soetomo, 2012: 121). Kebijakan yang dimaksud yaitu Peraturan Daerah
Kabupaten Majalengka Nomor 12 Tahun 2012 Tentang Pembentukan Desa Kramat Jaya. Pemikiran tersebut dijadikan sebagai alternatif solusi dalam upaya pemerataan pembangunan masyarakat. Kebijakan pemekaran Desa Kramat Jaya juga termasuk dalam kategori corak kebijakan self-regulatory. Kebijakan self-regulatory adalah kebijakan tersebut ditetapkan untuk memberikan kewenangan dalam mengatur sendiri daerahnya yaitu mencakup satuan wilayah tertentu (Ali dkk, 2012: 67).

\section{Peresmian Pemekaran Desa}

\section{Kramat Jaya}

Peresmian dilaksanakan pada Hari Selasa 4 Desember 2012 di Desa Kramat Jaya oleh Bapak Sutrisno Bupati Kabupaten Majalengka. Peresmian Desa Kramat Jaya ditandai dengan dilantiknya pejabat sementara untuk Kepala Desa yaitu Pak Umu Mu'minin.

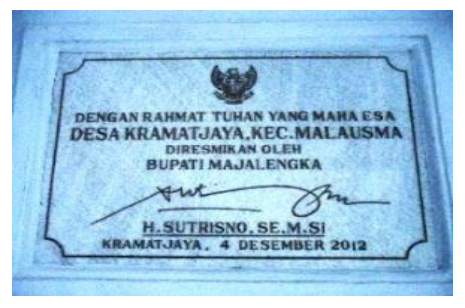

Gambar 2: Tugu

Pemekaran Desa Kramat Jaya termasuk bentuk perubahan yang direncanakan. Sebagaimana telah penulis paparkan bahwa pemekaran desa telah melalui berbagai perencanaan dan tahapan, mulai dari pembahasan di tingkat dusun, desa, kabupaten, hingga peresmian. Peresmian Perubahan yang dikehendaki atau direncanakan 
merupakan perubahan yang diperkirakan atau yang telah direncanakan terlebih dahulu oleh pihak-pihak yang hendak mengadakan perubahan di dalam masyarakat. Pihak-pihak yang menghendaki perubahan dinamakan agen of change yaitu seseorang atau sekelompok orang yang mendapat kepercayaan masyarakat sebagai pemimpin satu atau lebih lembaga-lembaga kemasyarakatan (Soekanto, 2007: 273). Agen of change dalam pemekaran Desa Kramat Jaya adalah kerjasama yang dibangun oleh Pak Umu Mu'minin beserta panitia pemekaran dan pemerintah Desa Werasari. Hingga akhirnya terwujud pemekaran Desa Kramat Jaya.

\section{DARI CIMANGLID KE KRAMAT}

JAYA: PEMEKARAN DESA DAN

IMPLIKASINYA TERHADAP

\section{KEHIDUPAN MASYARAKAT}

\section{A. Wajah Baru Desa Kramat Jaya}

\section{Sketsa Geografis Desa Kramat} Jaya

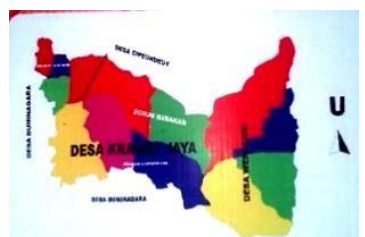

Gambar 3: Desa Kramat Jaya

Desa Kramat Jaya merupakan desa hasil pemekaran dari Desa Werasari. Kawasan Desa Kramat Jaya berupa perbukitan yang bergelombang dan termasuk kawasan dataran tinggi. Luas Wilayah Desa Kramat Jaya adalah $130 \mathrm{Ha}$.

Batas-batas Desa Kramat Jaya adalah: Sebelah Utara berbatasan dengan Desa Cipeundeuy dibatasi oleh parit; Sebelah Timur berbatasan dengan Desa Werasari dibatasi oleh Sungai Ciawi; Sebelah Selatan berbatasan dengan Desa Buninagara dibatasi oleh parit;dan Sebelah Barat berbatasan dengan Desa Buninagara dibatasi oleh parit kecil.

\section{Kependudukan Desa Kramat Jaya}

Data Kependudukan Desa Kramat Jaya dari 3 dusun ketika awal tahun 2011 saat pengajuan pemekaran desa berjumlah 1.666 jiwa dengan jumlah 401 kepala keluarga. Jumlah penduduk tiap tahun mengalami perubahan hingga pada 1 April 2016 jumlah penduduk Desa Kramat Jaya sejumlah 1.641 jiwa dengan jumlah laki-laki 815 jiwa dan perempuan 826 jiwa.

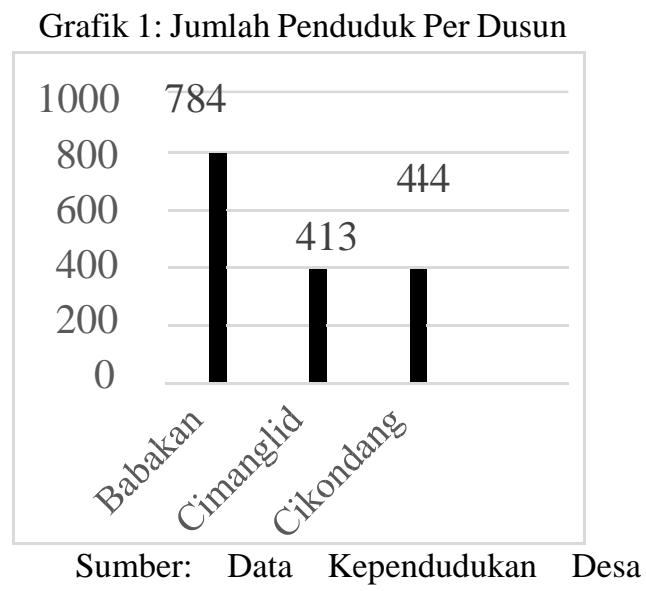

Kramat Jaya Bulan April 2016

\section{Pemerintahan Desa Kramat Jaya}

Masyarakat Desa Kramat Jaya saat ini pemerintahannya dipimpin oleh seorang Kepala Desa yaitu bernama Bapak Tatan Ciptan, dengan struktur pemerintahan desa sebagai berikut: 
Grafik 2 : Struktur Pemerintah Desa

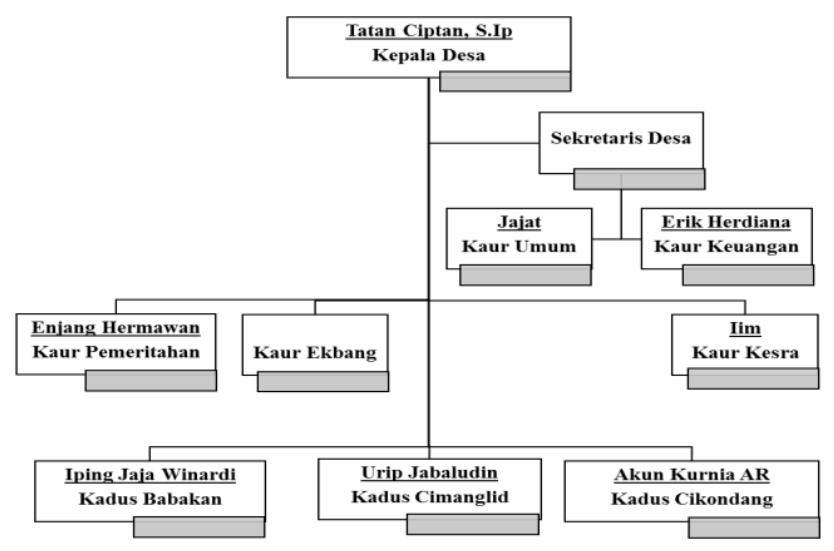

Sumber: Profil Desa Kramat Jaya

Tata administratif kewilayahan RT dan RW Desa Kramat Jaya adalah sebagai berikut:

Tabel 1: Pembagian RT, RW dan Dusun

\begin{tabular}{|l|c|c|c|c|c|c|c|c|c|c|c|c|}
\hline RT & 1 & 2 & 3 & 4 & 5 & 6 & 7 & 8 & 9 & 10 & 11 & 12 \\
\hline RW & \multicolumn{3}{|c|}{1} & 2 & \multicolumn{3}{|c|}{3} & \multicolumn{3}{|c|}{4} \\
\hline Dsn & \multicolumn{6}{|c|}{ Babakan } & \multicolumn{4}{c|}{ Cimanglid } & \multicolumn{4}{c|}{ Cikondang } \\
\hline
\end{tabular}

Sumber: Profil Desa Kramat Jaya

\section{Potret Kehidupan Sosial Ekonomi} Masyarakat di Desa Kramat Jaya

Kondisi kehidupan sosial ekonomi masyarakat Desa Kramat Jaya sangat beragam. Hal ini dapat terlihat dari mata percaharian yang heterogen seperti petani, buruh tani, pedagang, peternak, industri rumahan, guru, dan lain-lain.

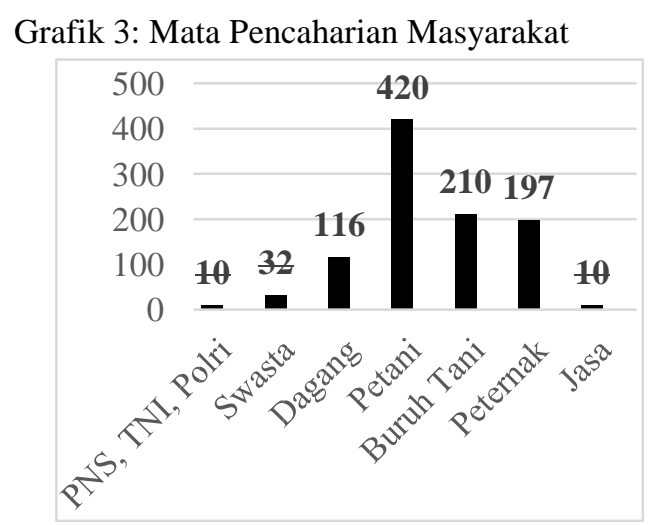

Sumber: Profil Desa Kramat Jaya

\section{Potret Sosial Budaya Masyarakat di Desa Kramat Jaya}

a. Agama

Penduduk Desa Kramat Jaya secara keseluruhan menganut agama Islam. Adapun fasilitas keagamaan yang tersedia adalah tempat ibadah berupa 3 Mesjid dan 8 mushola. Kegiatan keagamaan dikalangan anak-anak adalah pengajian di beberapa majelis taklim, perumahan, dan pesantren seperti di Dusun Cikondang dan TPA Al-Idris di Dusun Babakan.

b. Pendidikan

Pendidikan Desa Kramat Jaya didukung oleh fasilitas pendidikan formal. Fasilitas pendidikan yang tersedia yaitu 1 SD bernama SD Negeri Kramat Jaya dan 1 TK. Berikut Grafik Tingkat Pendidikan penduduk di Desa Kramat Jaya.

Grafik 4: Tingkat Pendidikan

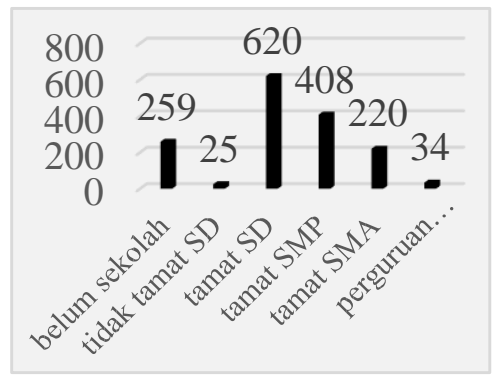

Sumber: Profil Desa Kramat Jaya

c. Kesehatan

Kesehatan penduduk Desa Kramat Jaya didukung oleh fasilitas kesehatan berupa Poskesdes yang berada disamping Kantor Desa. Poskesdes tersebut dilengkapi dengan petugas yaitu bidan desa. Selain itu terdapat pula 3 Posyandu yang tersebar di tiap dusun, paramedis 2 orang dan dukun bersalin terlatih 3 orang. 
d. Situs

Peninggalan sejarah yang ada di Desa Kramat Jaya yaitu berupa 2 situs makam yang bernama Makam Buyut Bagi di Dusun Babakan dan makam Brahma Jaya di Dusun Cimanglid. Makam Buyut Bagi lebih sering banyak pengunjungnya dibanding makam Brahma Jaya. Pengunjung yang datang ke makam Buyut Bagi tidak hanya bersasal dari sekitar Desa Kramat Jaya seperti Desa Werasari atau Desa Malausma saja, tetapi dari luar daerah seperti Madura, Palembang.

\section{B. Implikasi Pemekaran Desa Terhadap Kehidupan Masyarakat Desa Kramat Jaya}

Pemekaran Desa Kramat Jaya menjadi bagian dari mata rantai dampak euforia reformasi yang terjadi sejak ditetapkannya Undang-Undang Nomor Nomor 32 Tahun 2004 Tentang Pemerintah Daerah. Pemekaran Desa Kramat Jaya menjadi salah satu langkah dalam pembangunan masyarakat. Pembangunan masyarakat pada dasarnya sebuah proses perubahan, mobilisasi atau pemanfaatan sumber daya dan pengembangan kapasitas masyarakat untuk mencapai kondisi ideal atau masyarakat sejahtera (Soetomo, 2013: 31).

Pemekaran Desa Kramat Jaya merupakan pembangunan masyarakat yang menggunakan pendekatan transformation approach karena perubahan yang terjadi menghendaki adanya perubahan dalam kadar yang tinggi yaitu mencapai level struktur tingkat desa. Transformation approach adalah pendekatan pembangunan dalam masyarakat yang memiliki kadar tinggi dalam mewujudkan perubahan struktural (Soetomo, 2012: 119). Pemekaran Desa Kramat Jaya tidak hanya berimplikasi pada perubahan struktur administratif kewilayahan, kependudukan dan pemerintahan tingkat desa, tetapi berpengaruh pada perubahan pada aspekaspek lainnya. Perubahan-perubahan yang terjadi dalam masyarakat dapat mengenai nilai-nilai sosial, norma-norma sosial, pola-pola prilaku organisasi, susunan lembaga kemasyarakatan, lapisan-lapisan dalam masyarakat, kekuasaan dan wewenang, interaksi sosial dan lain sebagianya (Soekanto, 2007: 259).

\section{Reformasi Pemerintahan Desa Kramat Jaya}

Pemekaran Desa Kramat Jaya merupakan salah satu fenomena perubahan sosial yang berpengaruh terhadap kehidupan masyarakat setempat karena secara langsung merubah tatanan struktur dan sistem pemerintahan yang berjalan. Pemekaran desa telah mendorong masyarakat untuk membentuk lembaga-lembaga kemasyarakatan. Setelah berdiri sebagai desa otonom, masyarakat Desa Kramat Jaya membentuk institusi baru yaitu pemerintah desa dan institusi lainnya seperti Badan Permusyawaratan Desa (BPD) dan Lembaga Pemberdayaan Masyarakat (LPM) dan lembaga lainnya.

Penyelenggara pemerintahan Desa Kramat Jaya dibawah kepemimpinan Pak Umu Mu'minin, berjalan selama kurang lebih 10 bulan sejak peresmian desa 4 Desember 2012 sampai terpilihnya kepala desa hasil pemilihan umum masyarakat yaitu Bapak Tatan Ciptan. 
Karakteristik personal perangkat desa ketika dilihat dari tingkat pendidikan, rata-rata lulusan SLTA, sementara kepala desanya lulusan perguruan tinggi (Profil Desa Kramat Jaya). Hal tersebut secara tidak langsung berdampak pada kemampuan personal dalam melaksanakan tugas-tugasnya sebagai pemerintah desa, karena tingkat pendidikan dapat merefleksikan tingkat pemahaman dan pengetahuan.

Kelengkapan struktur perangkat desa sebagai penyelenggara pemerintahan masih dalam upaya penyempurnaan. Struktur perangkat desa sampai bulan Nopember 2015 bagian sekretaris desa yang sangat penting dalam urusan administrasi pemerintahan desa, belum ada yang menjabat. Selain itu, perangkat desa bagian Kepala Urusan Ekonomi Pembangunan (Kaur Ekbang) juga belum ada yang menjabat karena masih dalam proses pemilihan dan seleksi. Menyikapi hal ini, penyelenggaraan pemerintahan desa dalam kaitannya dengan administrasi tetap harus maksimal dan upaya yang dilakukan adalah dengan merangkap tugas. $^{8}$

Kinerja perangkat Desa Kramat Jaya belum mencapai titik maksimal. Hal ini disebabkan oleh berbagai faktor, utamanya adalah sumber daya manusia perangkat desa yang belum memiliki pengalaman sebagaimana desa-desa lain yang sudah berjalan cukup lama. Padahal seharusnya pemekaran wilayah mampu memberikan jaminan bahwa aparatur pemerintah baru memiliki kemampuan yang cukup untuk memaksimalkan fungsi-fungsi pemerintahan, sehingga dapat menjadi penggerak utama dalam meningkatkan kesejahteraan masyarakat (Pambudi, 2003:61).

Kondisi pemerintah desa yang baru dengan berbagai kendala personal yang ada, pembangunan masyarakat yang menjadi tanggung jawab pemerintah Desa Kramat Jaya terhadap masyarakatnya harus tetap dijalankan. Secara umum, adanya pemerintah desa baru perannya dapat dirasakan oleh masyarakat. Namun, pemahaman masyarakat terkait peran pemerintah masih fokus pada tanggung jawab dalam hal pelayanan publik saja. Pemahaman masyarakat terkait peran pemerintah dalam pelayanan publik dapat diklasifikasikan menjadi tiga pandangan.

Pertama, masyarakat memahami pelayanan publik adalah berupa pemberian bantuanbantuan langsung yang sampai pada masyarakat. Bantuan-bantuan yang dimaksud diantaranya adalah program Bantuan Langsung Tunai (BLT), Keluarga Harapan Sejahtera (PKH), dana Bantuan Operasional Sekolah (BOS), Beras Miskin (Raskin), bantuan bibit tanaman, hewan ternak dan bantuanbantuan lainnya yang bersifat sementara.

Kedua, pelayanan publik dipahami oleh masyarakat sebagai peran pemerintah desa dalam pembuatan persuratan administarsi seperti Kartu Keluarga (KK) dan Kartu Tanda Penduduk (KTP). 
Berkaitan dengan administrasi kependudukan, pelayanan menjadi mudah karena jarak yang semakin dekat antara masyarakat dengan pemerintah desa dan terjangkau oleh masyarakat.

Ketiga, sebagian masyarakat memahami peranan pemerintah baik dan tidaknya dinilai dari bentuk riil berupa pembangunan infrastruktur. Pembangunan infrastruktur setelah pemekaran desa terdapat peningkatan diantaranya yaitu berupa perbaikan jalan desa, pembangunan Poskesdes, irigasi pertanian, jalan, kios dan lainlain.

Dengan demikian pemekaran Desa Kramat Jaya dapat dikatakan mampu memperpendek rentang kendali pemerintah dalam penyelenggaraan pemerintahan. Hal tersebut telah mempermudah pemerintah dalam pengendalian pembangunan dan melaksanakan fungsinya sebagai pemerintah desa dalam meningkatkan kesejahteraan masyarakat meskipun belum mencapai titik maksimal.

Terpisahnya wilayah Desa Kramat Jaya dari Desa Werasri secara otomatis Desa Kramat Jaya telah mendapat bagian Anggaran Dana Desa (ADD) tersendiri dari pemerintah di atasnya. Dana tersebut dapat dikelola oleh pemerintah Desa Kramat Jaya untuk kesejahteraan masyarakat. Pemerintah Desa Kramat Jaya juga telah mempunyai kekuasaan dan kewenangan dalam melaksanakan berbagai pembangunan di wilayahnya.
2. Dampak Pemekaran Desa Terhadap Kehidupan Petani

a) Pembentukan Gabungan Kelompok Tani (Gapoktan)

Desa Kramat Jaya secara umum memiliki basis ekonomi yang bersumber pada sektor pertanian. Hal ini tergambar pada kondisi alam yang berupa hamparan lahan pertanian yang mengelilingi pemukiman warga. Melihat kondisi kehidupan masyarakat petani dan berdirinya Desa Kramat Jaya secara otonom, maka pemerintah Kecamatan Malausma menganjurkan kepada pemerintah desa dan masyarakat petani untuk melaksanakan program pengembangan ekonomi dengan membentuk kelembagaan masyarakat petani yaitu Gabungan Kelompok Tani atau Gapoktan.

Menanggapi anjuran pemerintah kecamatan tersebut, tahun 2012 tepatnya setelah pemekaran desa mulai merintis Gapoktan dengan bimbingan dari Badan Penyuluh Pertanian, Perikanan, dan Kehutanan (BP3K) Kecamatan Malausma. ${ }^{9}$

Berdasarkan data yang diperoleh dari BP3K Kecamatan Malausma, Gapoktan desa Kramat Jaya terdiri dari 6 kelompok tani yang diketuai oleh Pak Kuswandi.

\footnotetext{
9 Wawancara dengan Pak Kuswandi dan Pak

Tatan, Pak Umu
} 
Tabel 2: Data Kelompok Tani Desa Kramat

Jaya

\begin{tabular}{|l|c|l|c|}
\hline $\begin{array}{l}\text { Kelompok } \\
\text { Tani }\end{array}$ & $\begin{array}{l}\text { Jumlah } \\
\text { Anggota }\end{array}$ & Ketua & $\begin{array}{l}\text { Luas } \\
\text { Pertanian }\end{array}$ \\
\hline Cingaruy & 56 & Kuswandi & $5.2 \mathrm{Ha}$ \\
\hline Cintaga & 48 & Aep & $5.1 \mathrm{Ha}$ \\
\hline Cilopang & 53 & Mimif & $5.2 \mathrm{Ha}$ \\
\hline Ganda Asih & 48 & Udi & $5.1 \mathrm{Ha}$ \\
\hline Rukun Sari & 63 & Abdul & $5.2 \mathrm{Ha}$ \\
\hline Batu Karut & 44 & Budi Fikri & $5.2 \mathrm{Ha}$ \\
\hline
\end{tabular}

Sumber: Badan Penyuluh Pertanian,

Perikanan, dan Kehutanan (BP3K)

Kecamatan Malausma

b) Problematika Gapoktan

Gapoktan Desa Kramat Jaya pada awal pembentukan diketuai oleh Pak Kuswandi yang merupakan ketua kelompok tani Cingaruy. Pak Kuswandi menjabat sebagai ketua sampai tahun 2015 . Kemudian setelah itu mengalami kekosongan pengurus sampai April 2016 belum ada penggantinya, karena Pak Kuswandi mengundurkan diri. Kendala yang terjadi adalah minimnya sumber daya manusia yang berkehendak dan mampu dalam memimpin dan mengelola Gapoktan Kramat Jaya.

BP3K sebagai penyuluh Gapoktan biasa mengadakan bimbingan pertanian ke desa-desa, termasuk salah satunya adalah ke Desa Kramat Jaya. BP3K biasanya memberikan pelatihan petanian untuk meningkatkan hasil produksi. Salah satu arahan dalam pelatihan yaitu petani dianjurkan untuk melaksanakan sistem tanam yang serempak dalam satu waktu, dan pembibitan padi cukup 15 hari atau paling lambat 20 hari untuk mendapatkan hasil produksi padi yang banyak. Arahan tersebut sulit dilaksanakan oleh para petani karena berbagai kendala. ${ }^{10}$

Kendala-kendala yang di hadapi oleh para petani, diantaranya adalah minimnya ketersediaan jasa membajak lahan sawah atau sedikitnya petani yang memiliki mesin traktor. Diketahui bahwa petani Desa Kramat Jaya yang mempunyai mesin traktor hanya berjumlah 5 orang. Hal ini tidak sebanding dengan luasnya pesawahan yang membutuhkan tenaga atau jasa mesin traktor untuk membajak sawah, sehingga menimbulkan antrian cukup panjang untuk mendapatkan giliran membajak sawah. Selain itu, bibit padi yang sudah disemaipun cenderung lebih dari 20 hari karena lamanya menunggu giliran mesin traktor. Bahkan ada bibit padi yang sudah 2 bulan baru ditanam karena lama menunggu giliran mesin traktor. ${ }^{11}$

Melihat kondisi permasalahan pertanian Desa Kramat Jaya yang kekurangan alat produsi untuk membajak sawah yaitu berupa mesin traktor, para petani sebenarnya tidak terlalu membutuhkan bantuan berupa bibit padi atau bibit pohon. Berkaitan dengan hal tersebut para petani lebih membutuhkan fasilitas berupa mesin traktor yang dapat meringankan petani dan dapat digunakan untuk usaha juga. Selain 
itu dapat menanam padi sesuai dengan waktu yang sudah direncanakan.

Hambatan lain dalam kemajuan Gapoktan Desa Kramat Jaya dalam hal pengajuan bantuan atau program, salah satunya karena persyaratan administrasi secara legal berupa kepemilikan badan hukum. Setiap kelompok tani diharusakan memiliki badan hukum ketika ingin mendapatkan bantuan. Legalitas tersebut membutuhkan biaya yang cukup besar yaitu sekitar 1.5 juta. Hal ini menjadi hambatan yang cukup menghalangi kelompok-kelompok tani Desa Kramat Jaya untuk bisa berkembang, karena masyarakat petani berpandangan bahwa menikmati bantuan dari pemerintah saja belum, tetapi harus membayar iuran untuk mendapatkan legalitas badan hukum yang sangat mahal. ${ }^{12}$

c) Dampak Positif Keberadaan Gapoktan

Selama kurun waktu 2012 sampai 2015, Gapoktan Desa Kramat Jaya cenderung tidak berjalan, namun yang berjalan hanyalah kelompok tani. Keaktifan kelompok dilihat dari pola hubungan antar anggota, penyerapan bantuan yang sebelumnya diajukan oleh kelompoknya sendiri dan konsultasi dengan BP3K. Adapun kelompok tani yang pernah mendapatkan bantuan adalah kelompok Cingaruy, Cilopang, dan Rukun Sari.
Kelompok Cingaruy dan Rukun Sari pernah mendapatkan bantuan pada tahun 2014 berupa bibit padi dan tahun 2015 berupa bibit pohon cengkeh yang dibagikan ke anggotanya dengan pembagian 2 bibit per anggota. Selain bantuan bibit, kelompok Cingaruy bersama kelompok Cilopang mendapatkan kesempatan untuk mengikuti pelatihan wirausaha muda di Bandung dan konsultasi wirausaha pertanian di Bank Indonesia di Cirebon. ${ }^{13}$

Pemekaran Desa Kramat Jaya sedikitnya telah dirasakan oleh beberapa petani dalam kelompok tertentu karena membawa perubahan dengan adanya kelembagaan Gapoktan yang menaungi para petani. Hal ini dilihat dari beberapa kelompok yang telah mendapatkan bantuanbantuan meskipun tidak merata karena berbagai kendala. Pemerintah desa sebenanrnya telah mendukung atas terbentuknya Gapoktan. Misalnya ada kelompok yang mengadakan rapat, kepala desa ikut serta hadir dan memberikan dukungan. Selain itu, ketika ada kelompok yang berusaha mengajukan proposal bantuan ke BP3K dan membutuhkan persetujuan pemerintah desa, maka disetujui dan tidak dipersulit.

Keberadaan kelompok tani yang aktif dapat berdampak positif bagi anggotanya. Anggota dapat merasakan manfaat dari adanya 
kelompok tani. Misalnya ada anggota yang mengalami kendala dalam pertaniannya, maka saling membantu untuk mencarikan solusinya. Kelompok yang aktif di Desa Kramat Jaya seperti kelompok Cingaruy, ketika pesawahan padi anggotanya terserang hama, maka bersamasama mengatasinya dengan cara tradisional. Cara membasmi hama secara tradisional yaitu menggunakan kelapa hijau, daun pandan, jengkol dan lain-lain, sehingga akhirnya padi yang ditanam petani masih bisa dipanen.

d) Keberlanjutan Gapoktan

Pembentukan Gapoktan tersebut bermula dari anjuran pemerintah dan bermaksud untuk pemberdayaan masyarakat petani. Keberadaan Gapoktan tidak diimbangi dengan proses belajar sosial yang matang. Proses belajar sosial adalah proses interaksi antarwarga masyarakat dan lingkungannya untuk melahirkan perilaku individu dan tindakan bersama dalam rangka pemecahan berbagai persoalan (Soetomo, 2013: 409).

Kecacatan dalam proses sosial tersebut mengakibatkan lemahnya dorongan masyarakat untuk menerima keberadaan Gapoktan menjadi institusi lokal. Gapoktan menjadi bagian dari pembangunan yang menggunakan pendekatan cetak biru (blue print approach) dan bersifat top down karena pemerintah desa hanya sebagai pihak yang menerima dan menyalurkan program. Pendekatan cetak biru adalah pendekatan yang lebih menitikberatkan pada keseragaman yang diwujudkan dalam bentuk program pembangunan yang dirancang oleh pemerintah pusat (Soetomo, 2013: 300).

\section{Peningkatan Kesejahteraan Melalui Pembangunan Infrastruktur}

Pembangunan infrastruktur yang dibangun bermaksud untuk mempermudah aksesibilitas masyarakat dalam meningkatkan kegiatan atau aktivitas keseharian yang berkaitan dengan ekonomi, sosial, pendidikan, kesehatan, agama. Perkembangan pembangunan infrastruktur setelah pemekaran diantaranya adalah kantor desa, Pos Kesehatan Desa (Poskesdes), jalan desa, jalan penghubung, tembok penahan tanah (TPT) atau saluran irigasi, dan kios.

Pembangunan infrastruktur tersebut diperoleh dari programprogram pemerintah di atasnya yaitu bersumber dari APBN dan APBD yang berbentuk paket berupa dana, sementara pemerintah tingkat desa sebagai perantara dalam pelaksanaan program tersebut. Dalam hal ini, pembangunan telah menempatkan masyarakat hanya sebagai objek atau penerima program (Soetomo, 2012: 377). Berikut adalah paparan pembangunan infrastruktur di Desa Kramat Jaya.

Pertama, pembangunan jalan desa merupakan pembangunan infrastruktur yang sangat dirasakan manfaatnya oleh masyarakat setempat. Jalan desa ini melalui Dusun Cimanglid dan Dusun Babakan yang menghubungkan Desa Kramat Jaya dengan Desa Werasari, Desa 
Buninagara, dan Desa Cipeundeuy. Sebelum pemekaran Desa Kramat Jaya, kondisi jalan desa dalam keadaan rusak berat dan memprihatinkan dengan waktu yang cukup lama tidak mendapatkan perbaikan. $^{14}$

Sebelum pemekaran desa, masyarakat setempat sebenarnya telah mengeluhkan kerusakan jalan tersebut dan mengajukan untuk segera diperbaiki kepada pemerintah desa. Namun, dari pemerintah desa belum memberikan perhatian karena masih banyak agenda pembangunan lainnya yang menjadi prioritas pemeritah desa.

Pemekaran Desa Kramat Jaya membawa dampak positif terhadap kondisi jalan desa. Dampaknya adalah jalan desa mendapatkan anggaran dana untuk perbaikan dan akhirnya jalan tersebut bisa diperbaiki sebagaimana layaknya sebuah jalan yang layak dilalui oleh pengendara ataupun pejalan kaki dengan nyaman dan aman. Sehingga dapat mempermudah kegiatan sehari-hari masyarakat dalam berbagai sektor dan tidak membahayakan bagi para pengguna jalan. Kegiatan ekonomi baik produksi dan distribusi masyarakat lebih mudah dan efisien.

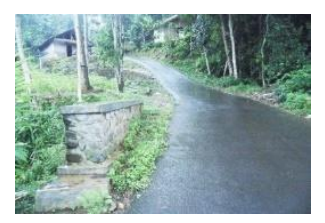

Gambar 4: Jalan Desa

Kedua, infrastruktur berupa kantor desa merupakan pusat kegiatan dalam penyelenggaraan pemerintahan desa dan menjadi pusat pelayanan masyarakat. Kantor Desa Kramat Jaya bertempat di Dusun Cimanglid beralamat di Jalan Kramat Jaya No. 01 Kecamatan Malausma Kabupaten Majalengka. Sejak itu aktivitas penyelenggaraan pemerintahan desa berpusat di kantor desa dan masyarakat bisa langsung mendapatkan pelayanan. Pemerintah desa dapat bekerja sebagaimana mestinya dan memanfaatkan kantor desa sebagai pusat pemerintahan. Pendirian kantor desa yang terletak di pertengahan desa tersebut telah memunculkan potensi ekonomi baru yaitu warung di dekat kantor desa menjadi ramai di datangi pengunjung.

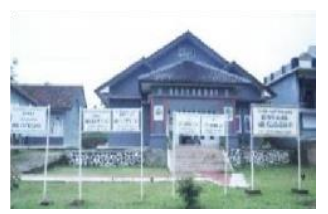

Gambar 5: Kantor Desa Kramat Jaya

Ketiga, Desa Kramat Jaya mendapatkan dana PNPM tahun anggaran 2013 digunakan untuk membangun Pos Kesehatan Desa (Poskesdes) yang berdiri tepat disamping kantor desa.

Pembangunan Poskesdes telah mempermudah masyarakat dalam mendapatkan pelayanan kesehatan. Bidan yang bertugas di Poskesdes adalah Ibu Herlis, A.Md.Keb.

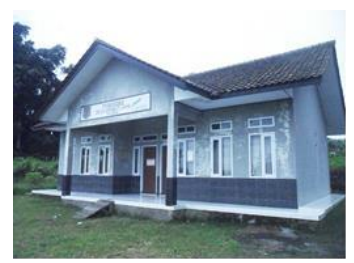

Gambar 6: Poskesdes

Sarana dan prasarana kesehatan mengalami peningkatan,

${ }^{14}$ Wawancara dengan Pa umu, Pak Iip 
yang dilihat dari jumlah Posyandu juga. Setelah pemekaran desa, Posyandu menjadi 3, yaitu bertempat di Dusun Cimanglid, Babakan dan Cikondang. Hal ini mendekatkan masyarakat dalam pemeriksaan kesehatan tiap bulannya, utamanya bagi anakanak di bawah 5 tahun seperti penimbangan berat badan, imunisasi, vaksin, dan konsultasi lainnya bagi ibu hamil dan menyusui. Pembangunan Poskesdes menjadi salah satu langkah dalam upaya peningkatan kualitas sumber daya manusia melalui kesehatan.

Keempat, pembangunan yang mendukung perairan dalam pertanian yaitu tembok penahan tanah (TPT) atau saluran irigasi. Dana pembangunan TPT diperoleh sebanyak 3 kali yaitu pada tahun 2014 yang bersumber dari Provinsi dan Kabupaten, dan pada tahun 2015 bersumber dari provinsi (Arsip Pembangunan Desa Kramat Jaya). TPT berfungsi untuk irigasi terhadap pertanian masyarakat, sehingga mempermudah perawatan petani pada tanaman padinya dan menghindari terjadinya longsor.

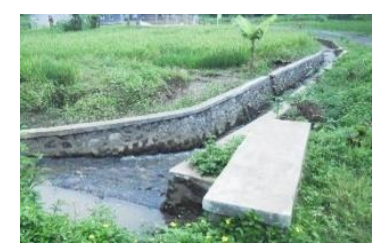

Gambar 7: TPT /Saluran Irigasi

Kelima,

Pembangunan infrastruktur lainnya adalah jalan yang menghubungkan Desa Kramat Jaya dengan Desa Cipeundeuy. Jalan penghubung tersebut panjangnya 400 meter dan lebarnya 2 meter yang masuk dalam area pesawahan di Dusun Babakan, sehingga dapat mempermudah akses para petani dalam melaksanakan aktivitas pertaniannya. Jalan penghubung ini secara tidak langsung mempermudah akses produksi dan distribusi pertanian masyarakat.

Selain itu, mempermudah masyarakat dalam berinterkasi dengan masyarakat lainnya.

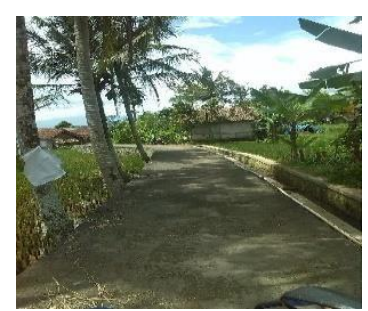

Gambar 8: Jalan Penghubung

Keenam, Bersamaam dengan dengan pembangunan jalan penghubung antara Desa Kramat Jaya dan Desa Cipeundeuy, pada tahun 2015 dibangun pula sarana ekonomi berupa Kios dekat kantor desa.

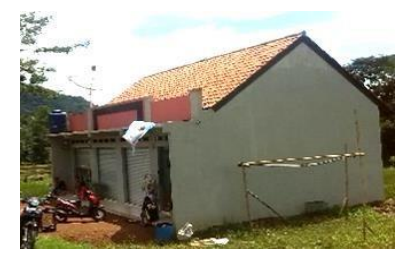

Gambar 9: Kios

Kios tersebut dengan sumber dana yang sama yaitu dari APBN. Pembangunan kios dilaksanakan dengan tujuan untuk memfasilitasi masyarakat yang ingin berwirausaha dan berjualan sebagai upaya dalam rangka meningkatkan kesejahteraan ekonomi masyarakat. Kios digunakan oleh masyarakat dengan sistem sewa yang masuk pada pendapatan kas desa. Berdirinya kios telah memunculkan potensi ekonomi baru yaitu peluang 
usaha dan pemasaran hasil produksi masyarakat.

\section{SIMPULAN}

Berdasarkan uraian hasil penelitian dan pembahasan, maka penelitian ini dapat disimpulkan sebagai berikut:

1. Pemekaran Desa Kramat Jaya merupakan salah satu langkah dalam rangka pembangunan masyarakat untuk mewujudkan kesejahteraan masyarakat. Proses pemekaran Desa Kramat Jaya adalah melalui tahapan-tahapan: pertama, adanya kebijakan berupa Undang-Undang Tentang Pemerintah Daerah sebagai pendorong pemekaran; Kedua, penjaringan aspirasi masyarakat di tingkat dusun; Ketiga, kajian rencana pemekaran Desa Kramat Jaya di tingkat desa; Keempat, pengajuan pemekaran ke pemerintah daerah; dan Kelima, peresmian desa baru.

2. Pemekaran Desa Kramat Jaya tidak hanya berimplikasi pada perubahan struktur administratif kewilayahan, kependudukan dan pemerintahan tingkat desa, tetapi berpengaruh pada perubahan pada aspek-aspek lainnya. Implikasi pemekaran Desa Kramat Jaya adalah sebagai berikut:

a. Reformasi pemerintahan Desa Kramat Jaya

Desa Kramat Jaya membentuk institusi Pemerintahan Desa dan lembaga BPD, dan LPM untuk menyelenggarakan pemerintahan desa. Setelah pemekaran desa, masyarakat dapat lebih dekat dengan pemerintah. Sehingga pelayanan yang diterima oleh masyarakat lebih cepat dan mudah karena tidak harus menempuh waktu yang lama atau jarak yang jauh. Dengan demikian pemekaran Desa Kramat Jaya dapat dikatakan mampu memperpendek rentang kendali pemerintah dalam penyelenggaraan pemerintahan.

b. Dampak pemekaran desa terhadap kehidupan petani

Setelah pemekaran Desa Kramat Jaya, terbentuk kelembagaan masyarakat petani yaitu Gabungan Kelompok Tani (Gapoktan). Gapoktan Desa Kramat Jaya terdiri dari 6 kelompok yaitu Cingaruy, Cintaga, Cilopang, Ganda Asih, Rukun Sari, dan Batu Karut. Namun, keberadaan Gapoktan tidak diimbangi dengan proses belajar sosial yang matang, sehingga Gapoktan cenderung pasif dan tidak berdampak secara berkesinambungan.

c. Peningkatan kesejahteraan melalui pembangunan infrastruktur.

Pembangunan infrastruktur yang sudah dilaksanakan adalah kantor desa, Pos Kesehatan Desa (Poskesdes), jalan desa, jalan penghubung, tembok penahan tanah (TPT) atau saluran irigasi, dan kios.

\section{DAFTAR PUSTAKA}

Ali, Farid, dkk. 2012. Studi Analisa Kebijakan Konsep, Teori dan Aplikasi sampel Teknik Analisa Kebijakan Pemerintah. Cetakan Ke-1. Bandung: PT Refika Aditama.

Bungin, M Burhan. 2012. Penelitian Kualitatif. Cetakan Ke-6. Ed Ke-2. Jakarta: Kencana Prenada Media Group.

Chalid, Pheni. 2005. Otonomi Daerah: Masalah, Pemberdayaan, dan Konflik. Cetakan Ke-1. Jakarta: Kemitraan.

El-Mawa, Mahrus. (Ed). 2011. Participatory Action Research (PAR) Pengabdian (Penelitian) kepada 
(Bersama) Masyarakat. Cetakan Ke-

3. Cirebon: LPM P3M IAIN Syekh Nurjati Cirebon.

Harfi, M. Zaini . 2013. Pelaksanaan

Pemekaran Desa Dan Pengaruhnya Terhadap Pelayanan Publik (Studi Di Desa Kuang Baru Kecamatan Sakra Kabupaten Lombok Timur). Junal Ilmiah. Fakultas Hukum Universitas Mataram Mataram.

Khaidir, Piet H. 2006. Nalar Kemanusiaan Nalar Perubahan Sosial. Cetakan Ke1. Jakarta: Teraju Mizan.

Moleong, Lexy J. 2013. Metodologi Penelitian Kualitatif. Cetakan Ke-31. Bandung: PT Remaja Rosdakarya.

Mulyana, Deddy. 2006. Metodologi Penelitian Kualitatif. Bandung: Remaja Rosda Karya.

Pambudi, Himawan S. et.al. 2003. Politik Pemberdayaan. Jalan Mewujudkan

Otonomi Desa. Yogyakarta: Lappera Pustaka Utama.

Profil Desa Kramat Jaya

Profil Desa Werasari

Proposal Pemekaran Desa Kramat Jaya

Raharjo, Budi. 1999. Pengantar Sosiologi Pedesaan dan Pertanian. Yogyakarta: Gajah Mada University Press.

Ratnawati, Tri. 2009. Pemekaran Daerah Politik Lokal dan Beberapa Isu Terseleksi. Cetakan Ke-1. Yogyakarta: Pustaka Pelajar.

Sapi'i, Imam, dkk. 2013. Dampak Pemekaran Desa Terhadap Pembangunan Infrastruktur Desa Pecahan, Studi Kasus Pemekaran Desa Bagorejo Kecamatan Gumukmas Kabupaten Jember. Artikel Ilmiah Hasil Penelitian Mahasiswa. I: 1-7.

Soekanto, Soerjono. 2007. Sosiologi Suatu Pengantar. Jakarta: PT Raja Grafindo Persada.
Soetomo, 2012. Pembangunan Masyarakat Merangkai Sebuah Kerangka. Cetakan Ke-2. Yogyakarta: Pustaka Pelajar.

2013. Strategi-strategi Pembangunan Masyarakat. Cetakan Ke-4. Yogyakarta: Pustaka Pelajar.

Sugiyono. 2011. Metode penelitian Kuantitatif Kuailitatif dan $R \& D$. Cetakan Ke-13. Bandung: Alfabeta.

Wijoyo, Tri Banjir Adi. 2013. Pemekaran

Desa Ditinjau dari Aspek Otonomi Daerah di Kecamatan Angkona Kabupaten Luwu Timur. Skripsi. Universitas Hasanudin: Fakultas Ilmu Sosial dan Ilmu Politik.

Winarno. 2008. Paradigma Baru Pendidikan Kewarganegaraan Panduan Kuliah di Perguruan Tinggi. Cetakan Ke-2. Jakarta: PT Bumi Aksara.

Peraturan Daerah Kabupaten Majalengka Nomor 12 Tahun 2012 tentang Pembentukan Desa Kramat Jaya

Peraturan Daerah Kabupaten Majalengka Nomor 17 Tahun 2006 Tentang Pembentukan, Penghapusan, Penggabungan Desa di Kabupaten Majalengka.

Undang-Undang No 32 Tahun 2004 Tentang Pemerintah Daerah

Peraturan Menteri Dalam Negeri Nomor 28 Tahun 2006 Tentang Pembentukan, Penghapusan, Penggabungan Desa dan Perubahan Status Desa Menjadi Kelurahan.

Peraturan Pemerintah Republik Indonesia Nomor 129 Tahun 2000 Tentang Persyaratan Pembentukan Dan Kriteria Pemekaran, Penghapusan Dan Penggabungan Daerah 